\title{
精神的健康における適応的諦観の意義と機能
}

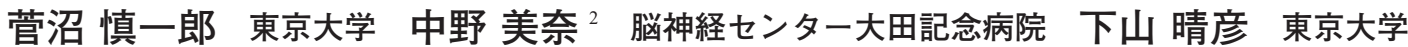

\section{Significance and function of adaptive resignation in psychological health}

\author{
Shinichiro Suganuma (University of Tokyo), Mina Nakano (Brain Attack Center Ota Memorial Hospital), \\ and Haruhiko Shimoyama (University of Tokyo)
}

\begin{abstract}
Recently, the adaptive function of resignation in psychological health is widely noted, especially from the standpoint of its relationship with mindfulness and acceptance. In this study, we developed two scales: one for measuring the stress-monitoring intention and one for measuring adaptive resignation. Then, we examined the relationship between stress-monitoring intention and psychological health in the light of the adaptive function of resignation. A questionnaire study was carried out with 600 Japanese workers in their 20s to 40s (300 males and 300 females: mean age $=35.37$ years, $S D=7.66$ years). The questionnaire's reliability and validity were demonstrated. Mediation analysis revealed mediated effects of adaptive resignation in the relationship between stress-monitoring intention and psychological health. This result suggested that stress-monitoring intention has a dual face to psychological health, and the adaptive resignation eases the negative relationship, and amplifies the positive relationship. Finally, the meaning of this study's results in terms of cognitive behavioral therapy and stress education in Japan are discussed.
\end{abstract}

Key words: resignation, give up, psychological health, cognitive behavioral therapy, stress.

The Japanese Journal of Psychology

2018, Vol. 89, No. 3, pp. 229-239

J-STAGE Advanced published date: July 14, 2018, doi.org/10.4992/jjpsy.89.16075

近年，認知行動療法の新しいアプローチとしてマイ ンドフルネスが注目されている。マインドフルネスと は,「今, この瞬間の体験に意図的に意識を向け，評 価をせずに，とらわれのない状態で，ただ観ること」 とされる（日本マインドフルネス学会, 2017）。この マインドフルネスに内在する要素としてマインドフル ネスストレス低減法として長年の実践を行ってきた Kabat-Zinn（1990 春木訳 2007）は「自分で評価をく ださないこと」，「忍耐づよいこと」，「初心を忘れない こと」,「自分を信じること」,「むやみに努力しないこ と」,「受け入れること」,「とらわれないこと」の7つ を挙げている。マインドフルネスは, 認知行動療法に

Correspondence concerning this article should be sent to: Shinichiro Suganuma, Department of Clinical Psychology, Graduate School of Education, University of Tokyo, Hongo, Bunkyo-ku, Tokyo 113-0033, Japan. (E-mail: p-sgnm@mail.ecc.u-tokyo.ac.jp)

本研究は科研費 $16 \mathrm{H} 02056$ の助成を受けた。

2 研究時所属: 東京大学大学院教育学研究科
ネガティブな思考や感情から距離をとるという新しい 機能をもたらした（杉浦，2008）ことから, マインド フルネスを中核とした認知行動療法は第 3 世代の認知 行動療法とされ, 認知行動療法のパラダイムシフトの 鍵となる重要概念と目されている。このマインドフル ネスと密接に関連するのがアクセプタンスであり, こ れは嫌悪的な状況に対する自分の反応をそのままにし ておくこと（熊野，2012）とされる。このアクセプタ ンスは「受容」と訳されることが多いが，日本語にお ける受容というよりもむしろ，「そのままにしておく」 という形でネガティブな私的事象へのコントロールを 捨てていく諦観的態度が重視されているといえよう。 これは, マインドフルネスの起源である仏教における 諦観の重視を受け継ぐものと考えられる。

この「諦観」を広辞苑（新村, 1998）で調べると, (a) 「入念に見ること」，（b）「（仏）たいかん」，(c)「あき らめること」という 3 つ意味がみられる。本研究で は (c)「あきらめること」の意味で「諦観」を用いる。 この「諦める」ことは従来, 心理学においてコーピン 
グスキルとして研究されてきた。Feifel \& Strack (1989) は葛藤状況に対する典型的なコーピングスタイルを “problem-solving”（問題解決）, “avoidance”（回避）, “resignation”（諦め）の3つであるとし，その程度を 測定する Life Situations Inventoryを開発している。こ のうち “resignation”（諦め）は，ストレスフルな状況 を変えようとすることなく，それに従ったり受け入れ る（Feifel \& Strack, 1989）ことであり,このようなコー ピング方略は主にネガティブで非適応的であると報告 されてきた。例えば Carver, Scheier, \& Weintraub (1989) により作成されたコーピング方略の測定尺度である COPE では “Mental disengagement” (心理的諦め) が コントロール感と有意な負の相関，不安と有意な正の 相関があること, “Behavioral disengagement”（行動的 諦め) がコントロール感, 自尊心, ハーディネスと有 意な負の相関, 不安と有意な正の相関があることが報 告されている。この状況は本邦でも同様で, 鈴木 (2004) は, 神村・海老原・佐藤・戸ヶ崎・坂野（1995）の作 成した Tri-Axial Coping Scale-24 を用いて, 大学生お よび成人を対象として調查を行い,「放棄・諦め型」 のコーピング攻略と, 抑うつ・不安や無気力の間に有 意な正の相関があることを報告している。また，小杉 他 (2004) の作成した職場ストレススケールを用いて, 会社員を対象として調査を行い, 因子分析の結果から 「諦め」型のコーピングを含んだ「問題放置」型コー ピングが「憂うつ感」や「緊張感」などと有意な正の 相関があることを報告している。このように「諦める」 ことのネガティブな側面が報告されることが多かった が, 近年では「諦め」の健康的な側面が注目を集めつ つある。上田（1996）によると，たとえ自己評価が低 くても, 狭義の自己受容としての「上手なあきらめ」が, 自己評価に対するメタレベルでの肯定度を高く保ち, 自尊心の向上に働きかけるという。これは元々の自己 評価も自尊心も平均よりも低い場合であり, 自尊心の 向上といっても尊大といえるまで高くなることはな く, 上田（1996）はこれこそが「あきらめ」の本質で あると主張している。青年期の諦めについて研究を 行った菅沼 $(2013,2015)$ も, 諦めは精神的健康に必 ずしもネガティブな影響を与えるとは限らず，諦める ことの多様なバリエーションの中で, 精神的健康への 機能に違いが存在するとし, 諦めの適応的側面につい て報告している。本研究は以上のような「諦める」こ との適応的な側面に関する臨床心理実践や先行研究の 動向を踏まえ, 特に社会的ニーズの高い労働者のス卜 レスを題材に, 適応的諦観とその精神的健康に対する 機能の検討を行うものである。

\section{自己のストレスへの気づきと社会的規範意識}

日本政府は近年, 労働者のメンタルヘルスやストレ スについて積極的な取り組みを行っており, 特にスト
レス対策に力を入れている。厚生労働省 (2000) は「事 業場に扔ける労働者の心の健康づくりのための指針」 を公示し, 心の健康づくりでは労働者自身がストレス に気づき対処する必要性を認識することが重要である と主張している。この指針は 2006 年に労働安全衛生 法第 70 条の 2 第 1 項に基づく「労働者の心の健康の 保持増進のための指針」に改正され，法律に基づく指 針になったことで，事業者はよりいっそう適正な実行 を求められることになった（島, 2006)。メンタルへ ルス不調の第一次予防に向けたアプローチとしては 「個人向けストレス対策」,「管理監督者教育」,「職場 環境等の評価と改善」などが挙げられている。この中 で「個人向けストレス対策」は, 労働者自身のセルフ ケア能力を向上させ, 自己のストレスに早期に気づき, 適切に対処できるようになることを支援するものであ る（島津，2013）。このような国の指針は，有効性が 高いとされるストレスに対する認知行動的アプローチ に則ったものである。認知行動療法においては, クラ イエントが自分の心理的問題に自分で対処できるスキ ルを身につけることが目標であり，環境からの刺激と 自身の反応への気づきを促すセルフモニタリングは効 果測定だけでなく，行動変容のきっかけとして非常に 重要視されている（Westbrook, Kennerley, \& Kirk, 2011 下山監訳 2012)。

一方で, 我が国に扔ける労働者個々人レベルでのス トレスのモニタリングやセルフケアには限界があると 考えられる。というのも，日本人は「社会人として他 者に迷惑をかけてはいけない」,「組織の秩序を乱して はならない」,「その場の空気を読んで適切に行動す心゙ き」といった社会的な規範意識が強いためである。例 えば高橋（2005）は，江戸時代より滅私奉公という倫 理観があり, 日本人の集団帰属意識の強さの原点と なっていることから, 日本人の職業観を検討する際は, 歴史的, 文化的, 社会的な文脈の中で位置づけていく 必要があると主張している。日本人の労働観について 調査した清川・山根（2004）も，会社に対して「尽く したい」と回答した割合が近年増加していること，そ の理由の 1 つとして, バブル崩壊後の厳しい雇用情勢 のもとで, 会社のために懸命に働かなくてはならない という危機感の表れと解釈できると述べている。なお, このような「和をもって尊しとなす」傾向は文化レべ ルでも報告されてきたことであり,例えば高田（1999） は，オーストラリア・カナダ・日本を比較した質問紙 調査による国際比較研究から，ヨーロッパ系のオース トラリア人・カナダ人では相互独立的自己観が優勢で あり, 日本人では相互協調的自己観が支配的であるこ とを示している。このような仕事場面における相互協 調性や組織への強い帰属意識は, 自己よりも所属する 集団を優先することに繋がり，その結果として自己の ストレッサーやストレス反応から目を背けてしまう可 
能性がある。実際に，宗像（1996）は，他者に気に入 られようとして自分の本音を抑えその期待に応えよう とする特性を自己抑制型行動特性（イイコ行動特性） として概念化しており，日本人に多くみられること， 抑うつとの関連が高いことを報告している（山本・宗 像, 2012)。これらの研究からは, 日本人は自己のス トレッサーやストレス反応への気づきから意識的また は無意識的に目を背け，思考や感情を表出せずに抑え 达むことで結果的に環境に適応する傾向が強いと捉え ることができるだろう。そのため，自身のストレスに ついて把握するのが苦手であるといえ, 自己のストレ ス，つまりストレッサーやストレス反応を意識しよう とすることが, 結果としてストレス反応を高めてしま う可能性も考えられる。そのため，ストレスの気づき を測定するにあたっては，ストレッサーやストレス反 応そのものだけでなく，ストレッサーやストレス反応 に関するモニタリングの志向性を測定することが重要 であると考えられる。

このようなストレスを意識することによる悪影響を 緩和するものとして, 本研究では自己や自己を取り巻 く状況に対する諦観的態度に着目する。具体的には, 前述した諦観に関する先行研究に基づき,「自己や状 況のネガティブな側面をそのまま受け入れつつも，そ こにこだわらない前向きな態度」として定義する。こ れは，必ずしも物事の現状をポジティブな枠組みで捉 え直すことではなく，あくまで現状のネガティブな側 面はネガティブなまま，あるがままに受け入れ，「で もまあ, なんとかやっていけるだろう」といった楽観 的な諦観をもって思い悩まないという認知的態度であ る。このような適応的諦観が, 社会的な規範意識を根 強く有する日本人にとって, ある種のレジリエンスと して機能する可能性がある。

\section{本研究の仮説と目的}

以上の問題意識を踏まえると, 精神的健康の向上を 目的とした日本での認知行動的アプローチの実践, 特 に近年実施されてきたストレス対策において，従来言 われてきたようなストレスに対する気づきを促すのみ では不十分であり，ネガティブな気づきに対する楽観 的で適応的な諦観をもつことが重要であるという仮説 が得られる。この仮説を検討するため, 本研究ではス トレスへのモニタリング志向と適応的な諦観を測定す る尺度を開発し，ストレスへのモニタリング志向と精 神的健康の関連について, 適応的な諦観の役割を踏ま え検討を行う。

ストレスへのモニタリング志向について，ストレス を測定する尺度は多数存在する。例えば, 旧労働省委 託研究班のストレス測定グループによって開発された 「職業性ストレス簡易調查票」（加藤，2000）の「当該 労㗢者の心理的な負担による心身の自覚症状に関する
項目」に該当するのは，「活気がわいてくる」，「内心 腹立たしい」,「イライラしている」など 29 項目である。 鈴木他（1997）が開発した心理的ストレス反応尺度は, 「悲しい気分だ」「怒りを感じる」，「不愉快だ」など 18 項目の質問で構成されている。しかし，これらは ストレッサーによる心身の反応の有無，つまり「気づ いているかどうか」を直接問うものであり，当然そこ には意識的に気づいているものしか反映されない。本 研究では，ストレッサーやストレス反応に「自分で気 づこうと思っているのかどうか」，「気づけるように心 がけているのかどうか」というモニタリングの志向性 を測定する尺度を開発する。

また，適応的諦観については，諦観について着目し た尺度自体がほとんど見当たらない。関連する尺度と しては, わりきり志向（浅野，2010）や諦めることに 対する認知（菅沼, 2014）があるが，これらはいずれ も割り切りや諦め自体に対する認知を測定するもので あり, 適応的諦観とは異なる。そこで本研究では, 上 述した「自己や状況のネガティブな側面をそのまま受 け入れつつも，そこにこだわらない前向きな態度」と いう定義に基づき, 適応的諦観を測定する尺度を開発 する。

その後，ストレスへのモニタリング志向が適応的諦 観を媒介して精神的健康と関連するというモデルを検 証する。本研究の仮説は, ストレスへのモニタリング 志向は, (a) ポジティブな精神的健康へ負の直接効果 と適応的諦観を介した正の間接効果を示す，(b) ネガ ティブな精神的健康へ正の直接効果と適応的諦観を介 した負の間接効果を示す, という 2 点である。

\section{方法}

\section{尺度の開発}

本研究の問題意識に基づき, 自分のストレッサーお よびストレス反応への気づきの志向性抢よびそのそし さを測定する「ストレスへのモニタリング志向」と， 自己や状況に対して諦めつつ受容する態度を測定する 「適応的諦観」の 2 つ構成概念をそれぞれ測定する 尺度を開発することとした。「ストレスへのモニタリ ング志向」に関しては, 認知行動療法における人間と 環境の相互作用モデル (Westbrook et al., 2011 下山監 訳 2012）に基づき，ストレッサーとストレス反応へ のモニタリング志向性についての項目を収集した。ス トレッサーについては環境からの刺激内容や場面に対 するモニタリング志向性，ストレス反応についてはス トレッサーに対する自身の感情や身体状態に関するモ ニタリング志向性についての項目となっている。なお, 認知行動療法では個人のシステムを認知・感情・行動・ 身体の 4 つに大別しているが, 今回はストレス反応と して代表的な感情と身体の反応について取り上げるこ 
ととした。「適応的諦観」に関しては，菅沼（2015） の建設的な諦めるプロセスに基づき, 項目を収集した。 菅沼（2015）は「諦める」プロセスを「未練型」「割 り切り型」,「再選択型」の 3 つに分類し, 自らの欲求 が達成困難あるいは達成不可能であるというネガティ ブな気づきをきっかけとしつつもそこにこだわらず, 違う夢や目標に前向きに向かう建設的な諦めるプロセ スを報告している。その中で生じる「周囲からの尊重」, 「自己の発見と深まり」，「目標に対する気づき」，「諦 めるしかない」という 4 つの建設的な認知とそのイン タビューデータを参考に, 適応的諦観に関する項目案 を作成した。なお，この作業は臨床心理士有資格者で 臨床心理学を専門とする大学教員 3 名で実施した。「ス トレスへのモニタリング志向」尺度は, 最終的に 12 項目 4 件法（「そう思わない」,「あまりそう思わない」, 「ややそう思う」，「そう思う」）で構成された。「適応 的諦観」尺度は, 最終的に 14 項目 4 件法（「そう思わ ない」,「あまりそう思わない」,「ややそう思う」,「そ う思う」）で構成された。

\section{実施手続き}

2016 年 9 月に, インターネット調查会社の保有す る 20-49 歳の常勤雇用の会社員 600 名 (男性 300 名, 女性 300 名）へオンラインでの調査を実施し，得られ たデー夕を分析した。平均年齢は 35.37 歳 $(S D=7.66)$ であった。実施の際には, 調査の目的と倫理的配慮に 関する説明を載せ, デー夕は統計的に処理され，個人 が特定される形で利用されないことを説明した。

\section{質問紙の構成}

上記で作成した尺度案の他, 以下の質問紙を用いた。 二次元レジリエンス要因尺度 二次元レジリエンス 要因尺度は 21 項目 5 件法で, 個々人のレジリエンス を導く多様な要因のうち, 資質的レジリエンス要因と 獲得的レジリエンス要因の 2 つのレジリエンス要因を 測定する尺度である。（項目例 : 決めたことを最後ま でやりと拉すことができる（資質的レジリエンス）， 嫌な出来事があったとき, 今の経験から得られるもの を探す (獲得的レジリエンス))。妥当性・信頼性が確 認されており（平野，2010）, 尺度得点が高いほど多 くのレジリエンス要因を有し，適応的であることを示 す。本研究では並存的妥当性検討のために使用し,「ス トレスへのモニタリング志向」については認知行動理 論 (Westbrook et al., 2011 下山監訳 2012),「適応的諦観」 については菅沼（2015）の建設的な諦めるプロセスを 基に, 精神的健康向上のためのレジリエンス要因とし て捉え，いずれとも中程度の正の相関があると想定し た。本研究における内的整合性は資質的レジリエンス $\alpha=.86$, 獲得的レジリエンス $\alpha=.79$ であった。

日本語版 Acceptance and Action Questionnaire-II 7
項目版 日本語版 Acceptance and Action QuestionnaireII 7 項目版（以下, AAQ-II とする) は 7 項目 7 件法で, アクセプタンス＆コミットメント・セラピー（以下， ACT とする）における「体験の回避」を測定する尺 度であり，心理的非柔軟性の指標として用いた（項目 例 : 自分の苦しい経験や記憶は，私が大事にしている 生活を送ることを困難にする)。嶋・柳原・川井・熊 野（2013）によって信頼性と妥当性が確認されており, 尺度得点が高いほど心理的柔軟性が低く, 不適応的で あることを示す。本研究では並存的妥当性検討のため に使用した。ACTではアクセプタンスという形で諦 観的態度が重視されていることから，「適応的諦観」 を心理的柔軟性の指標として捉え, 中程度の負の相関 があると想定した。本研究に㧍ける内的整合性は $\alpha=$ .85であった。

自己肯定感尺度 ver2 自己肯定感尺度 ver2 は 8 項 目 4 件法で,「自己に対する前向きで，好ましく思う 態度や感情（田中, 2008)」としての自己肯定感を測 定する (項目例 : 私は, 自分のことを大切だと感じる)。 妥当性・信頼性が確認されており（田中，2008）, 本 研究に扔ける内的整合性は $\alpha=.81$ であった。尺度得 点が高いほど自己肯定感が高く, 適応的であることを 示す。本尺度は他の自尊心や自己肯定感を測定する尺 度と異なり，日本の文化的特性を踏まえた自己肯定感 を測定するという点で並存的妥当性検討のために使用 した。「ストレスへのモニタリング志向」は認知行動 理論（Westbrook et al., 2011 下山監訳 2012）から自己 肯定感と関連が深いと考えられるが，自己のストレス への意識がストレス反応を高めてしまうという本研究 の仮説を基にすると, 従来考えられていたよりも関連 が弱いと考えられ，低い正の相関があると想定した。 「適応的諦観」は自己や状況のネガティブな側面をそ のまま受け入れるという点で自己肯定感と関係が深い と考えられ，中程度の正の相関があると想定した。

日本語版 Warwick-Edinburgh Mental Well-being Scale

日本語版 Warwick-Edinburgh Mental Well-being Scale は 14 項目 5 件法で, 快楽主義的側面と幸福主義的側面の 両側面を反映したポジティブな精神的健康状態を測定 し (項目例 : 自分が役に立つ人間だと感じる), 妥当性・ 信頼性が確認されている（菅沼・平野・中野・下山, 2016; Tennant et al., 2007)。本研究に打ける内的整合性 は $\alpha=.91$ であった。媒介分析によるモデル検討の際に ポジティブな精神的健康の指標として用いており, 尺 度得点が高いほどポジティブな精神的健康が高く, 適 応的であることを示す。

Public Health Research Foundation ストレスチェッ クリスト・ショートフォーム Public Health Research Foundation ストレスチェックリスト・ショートフォー ムは 24 項目 3 件法で, 日常生活におけるストレス反 応を心理的側面と身体的側面から多面的に測定する尺 
Table 1

ストレスへのモニタリング志向の因子分析結果

\begin{tabular}{lc}
\hline & 因負荷量 \\
\hline 自分がどのような場面で不安になるのか気づいている & .73 \\
自分がどういう事でイライラしがちなのか気づいている & .71 \\
自分がどういうことで落ち込みがちなのか気づいている & .69 \\
自分にとって何がストレスになっているか意識するようにしている & .61 \\
自分の体調を意識するようにしている & .59 \\
自分がどの程度まで無理がきくか注意している & .55 \\
気分が落ち込んだときは, その原因を探るようにしている & .54 \\
嫌なことは嫌とその場で気づく & .54 \\
\hline
\end{tabular}

Table 2

適応的諦観の因子分析結果

\begin{tabular}{lc}
\hline & 因子負荷量 \\
\hline 失敗しても, なんとかやっていける気がする & .77 \\
嫌なことがあってもなんとかなる気がする & .70 \\
うまくいかなくても何かしら意味があると思う & .67 \\
うまくいかないことがあっても仕方がないと思える & .63 \\
自分に弱点があってもまあいいかと思える & .62 \\
自分にとって何が大切か気ついている & .58 \\
周りに頼ることがあっても良い & .58 \\
自分には自信を持つべきだ & .56 \\
自分の強みを意識するようにしている & .55 \\
嫌なことでもましな面を探すようにしている & .53 \\
\hline
\end{tabular}

度である（項目例 : 何か仕事をするときは, 自信をもっ てできない)。妥当性・信頼性が確認されている（今 津他, 2006)。本研究における内的整合性は $\alpha=.92$ で あった。媒介分析によるモデルの検討の際にネガティ ブな精神的健康の指標として用いており，尺度得点が 高いほどネガティブな精神的健康が高く, 不適応的で あることを示す。

\section{結果}

\section{探索的因子分析による因子構造の検討}

ストレスへのモニタリング志向尺度原案および適応 的諦観尺度原案のそれぞれについての探索的因子分析 （最尤法, プロマックス回転）を行い, 固有值の減衰 状 況 $(3.95,1.92,0.90,0.79 \cdots / 4.52,2.03,1.17,0.79 \cdots)$ からストレスへのモニタリング志向は 1 - 2 因子構造, 適応的諦観は $1-3$ 因子構造と考えられたが, 1 因子 構造以外の場合は第 2,3 因子の項目数が少なく，ま た事前に想定した構成概念に即した解釈が困難であっ たため, 解釈可能性の観点からそれぞれ 1 因子構造が 妥当であると判断した。それぞれ，因子負荷量が.40 以下の項目を削除し，再度探索的因子分析を行った結
果，ストレスへのモニタリング志向尺度は 8 項目，適 応的諦観尺度は 10 項目となった（Table 1, Table 2)。 意味のまとまりや表現の重複を考慮し，最終的にそれ ぞれ因子負荷量の上位 5 項目ずつを採用した。なお, 最終的に採用されたストレスへのモニタリング志向尺 度の平均值と標準偏差は $M=14.05, S D=2.72$, 適応的 諦観尺度の平均值と標準偏差は $M=13.74, S D=2.80$ であり，分布の極端な偏りはみられなかった。それぞ れに対し，年代と性別を独立変数とする 2 元配置分散 分析を行ったところ，ストレスへのモニタリング志向 については，年代・性別の主効果，交互作用のいずれ も有意ではなかった。適応的諦観については, 年代の 主効果のみ有意であり, $(F(2,594)=3.82, p<.05)$, Bonferroni 法による多重比較の結果, 20 代 $<40$ 代で あった。

\section{確認的因子分析}

2つの尺度に関してそれぞれ，探索的因子分析に よって得られた 1 因子を潜在変数とし, 潜在変数間と そこから潜在変数を構成する当該項目にパスを引いた 1 因子モデルで確認的因子分析を行った。全てのパス 係数および相関係数は有意であった。ストレスへのモ 
Table 3

並存的妥当性検討のために用いた変数間の相関

\begin{tabular}{|c|c|c|c|c|c|c|}
\hline & 1 & 2 & 3 & 4 & 5 & 6 \\
\hline 1 ストレスへのモニタリング志向 & & $.38 * *$ & $.27 * *$ & $.45 * *$ & $.17 * *$ & $.16^{* *}$ \\
\hline 2 適応的諦観 & & & $.52 * *$ & $.50 * *$ & $-.22 * *$ & $.42 * *$ \\
\hline 3 資質的レジリエンス & & & & $.71 * *$ & $-.19 * *$ & $.53 * *$ \\
\hline 4 獲得的レジリエンス & & & & & $-.10 *$ & $.49 * *$ \\
\hline 5 心理的非柔軟性 & & & & & & $-.47 * *$ \\
\hline 6 自己肯定感 & & & & & & \\
\hline
\end{tabular}

Table 4

媒介分析に用いた変数間の相関

\begin{tabular}{lcccc}
\hline & 1 & 2 & 3 & 4 \\
\hline 1 ストレスヘのモニタリング志向 & & $.38^{* *}$ & $.21 * *$ & $.16^{* *}$ \\
2 適応的諦観 & & & $.48 * *$ & $-.17^{* *}$ \\
3 ポジティブな精神的健康 & & & & $-.34 * *$ \\
4 ネガティブな精神的健康 & & & & \\
\hline$* * p<.01$ & & & &
\end{tabular}

ニタリング志向尺度のモデルの適合度の指標は, GFI $=.99, \mathrm{AGFI}=.96, \mathrm{CFI}=.98, \mathrm{RMSEA}=.07$, 適応的 諦観尺度のモデルの適合度の指標は, GFI = .98, $\mathrm{AGFI}=.95, \mathrm{CFI}=.98, \mathrm{RMSEA}=.09$ と十分な適合度 を示した。

\section{信頼性の検討}

ストレスへのモニタリング志向尺度および適応的諦 観尺度に関して, 内的整合性の検討のために Cronbach の $\alpha$ 係数を算出したところ，それぞれ $\alpha=.80, .81$ と 十分な信頼性が示された。

\section{並存的妥当性の検討}

ストレスへのモニタリング志向および適応的諦観に 関して，資質的レジリエンス，獲得的レジリエンス， 心理的非柔軟性, 自己肯定感との Pearsonの相関係数 を算出した（Table 3)。ストレスへのモニタリング志 向は, 資質的レジリエンスと $r=.27$, 獲得的レジリエ ンスと $r=.45$, 心理的非柔軟性と $r=.17$, 自己肯定感 と $r=.16$ の相関を示した。適応的諦観は, 資質的レ ジリエンスと $r=.52$, 獲得的レジリエンスと $r=.50$, 心理的非柔軟性と $r=-.22$, 自己肯定感と $r=.42$ の相 関を示した。

\section{媒介分析によるモデルの検討}

仮説を元に，ストレスへのモニタリング志向が適応 的諦観を介して，最終的にポジティブあるいはネガ ティブな精神的健康と関連するというモデルを統計分 析プログラム HAD（清水, 2016）による媒介分析に
よって検討した。Table 4 に各変数の単相関を示す。

ストレスへのモニタリング志向を独立変数, ポジ ティブな精神的健康を従属変数とした媒介変数なしモ デルでは， $\beta=.21(p<.01)$ であり，そこに諦観的 態度を媒介変数として組み込んだモデルでは, 標準化 総合効果が $\beta=.21(p<.01)$, 標準化直接効果が $\beta=$ $.03(n s)$, 標準化間接効果が $\beta=.18(p<.01)$ であっ

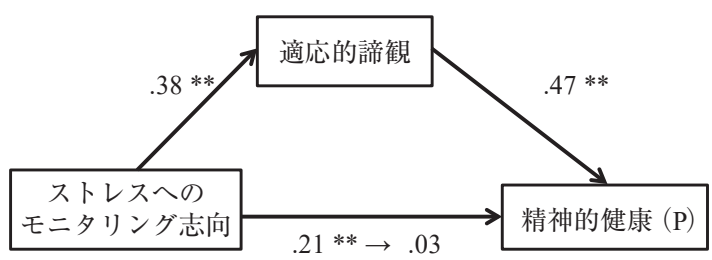

Figure 1. ポジティブな精神的健康との媒介分析結果。 注）Pはポジティブを示す。係数は標準化係数であり，矢印の右 側は媒介変数投入後の直接効果を示す。

** $p<.01$

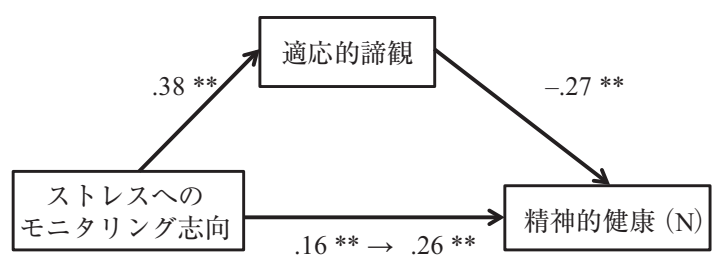

Figure 2. ポジティブな精神的健康との媒介分析結果。

注） $\mathrm{N}$ はネガティブを示す。係数は標準化係数であり，矢印の 右側は媒介変数投入後の直接効果を示す。

** $p<.01$ 
た（Figure 1)。ストレスへのモニタリング志向を独立 変数, ネガティブな精神的健康を従属変数とした媒介 変数なしモデルでは, $\beta=.16(p<.01)$ であり, そ こに適応的諦観を媒介変数として組み込んだモデルで は, 標準化総合効果が $\beta=.16(p<.01)$, 標準化直接 効果が $\beta=.26(p<.01)$, 標準化間接効果が $\beta=-.10(p$ <.01）であった（Figure 2)。95\% 信頼区間推定にバ イアス修正法を用いたブートストラップ法（標本数 10,000）により間接効果を検討したところ，ポジティ ブな精神的健康 $(\beta=.18)$ およびネガティブな精神的 健康（ $\beta=-.10 ）$ のいずれの場合も有意であった。

\section{考察}

\section{尺度の信頼性と妥当性}

本研究ではまず，ストレスへのモニタリング志向と 適応的諦観を測定する尺度の開発を行った。探索的・ 確認的因子分析の結果から，尺度作成時に想定された 内容が因子として確認された。RMSEAの数值がやや 高いものの, いわゆる Golden rule (星野・岡田・前田, 2005）の 1 つである 0.1 は下回っており，また他の適 合度指標が.95 以上を上回っていることから，各尺度 が一定の内容妥当性・構成概念妥当性を有することが 確認されたといえる。また，いずれの尺度も内的整合 性が高く, 各尺度について一定の信頼性が確認された といえる。

各尺度の記述統計量について分散分析を行った結 果，ストレスへのモニタリング志向については，今回 対象とした成人前期一中期の労働者の間で, 性別・年 代において大きな差がみられなかった。通常であれば 年齢を重ねるごとに研修や人事面接等を通じてメンタ ルヘルスに対する理解が深まり，ストレスへのモニタ リング志向が高まることが期待されるが，必ずしもそ うはなっておらず，一定であることが示唆された。適 応的諦観においては年代の主効果が得られ，20代< 40 代となっていた。仕事や家庭における経験を通じ て，年歯を重ねるにつれてネガティブな出来事に対す る受け止め方を身につけていく傾向が存在する可能性 がある。

各尺度の並存的妥当性について，ストレスへのモニ タリング志向と適応的諦観はそれぞれ, 資質的レジリ エンスと弱い正の相関，中程度の正の相関，獲得的レ ジリエンスといずれも中程度の正の相関を示した。ス トレスへのモニタリング志向と資質的レジリエンスの 関係は想定していたよりもやや弱いものであったが, それ以外は当初想定していた相関関係がみられたこと になる。これらの結果は, ストレスへのモニタリング 志向と適応的諦観が精神的健康の向上のためのレジリ エンス要因として捉えられるという本研究の仮説を支 持している。ストレスへのモニタリング志向と自己肯
定感とは相関がみられなかったが，ストレスへのモニ タリング志向と自己肯定感はどちらも適応的諦観と中 程度の正の相関を示しており，媒介分析で示されたス トレスへのモニタリング志向の精神的健康に対するア ンビバレントな機能が関係し, 正負の関連が打ち消し あった可能性が考えられる。

一方で適応的諦観は自己肯定感と想定通り中程度の 相関を示しており，日本の文化的特性を踏まえた自己 肯定感とも近い関係にあると考えられる。心理的非柔 軟性については, 適応的諦観と弱い負の相関がみられ た。心理的非柔軟性について, 今回用いた AAQ-II で 測定しているのは体験の回避であり，思考や感情，記 憶, 身体感覚などの私的出来事の頻度や内容を変えよ うとする行動のことを指す（嶋他, 2013）が, この体 験への回避が常に非適応的に働くとは限らない。体験 の回避をした後の適応性については問わない AAQ-II と, 体験を回避せず適応的な態度を測定する本尺度と いう違いが，想定したよりも低い負の相関という形で 確認されたと考えられる。

このように一定の妥当性・信頼性が確認されたもの の, ストレスへのモニタリング志向と適応的諦観のど ちらについても十分な妥当性信頼性の検討ができたと は言い難い。本研究で開発された尺度は試行的なもの として位置づけ, 今後構成概念および測定概念の精緻 化, 尺度項目の吟味, ストレッサーやストレス反応を 含めた関連概念との並存的妥当性, 再検査信頼性と いった作業を行うことで発展させていく必要があると いえる。

\section{ストレスへのモニタリング志向および適応的諦観と精 神的健康との関連}

ストレスへのモニタリング志向の精神的健康に対す る機能に焦点を当て，媒介変数として適応的諦観を用 いた媒介分析の結果からは，適応的諦観がストレスへ のモニタリング志向と精神的健康の媒介要因として機 能していることが明らかになった。適応的諦観を考慮 しない分析において，ストレスへのモニタリング志向 はネガティブな精神的健康を高める機能を有してお り,これは自己のストレスを意識しようとすることが, 結果としてストレス反応を高めてしまうという先行研 究から得られた仮説と一致している。しかしながら, 諦観的態度の媒介効果を考慮すると，ストレスへのモ ニタリング志向はネガティブな精神的健康に対して正 の直接効果を有する一方で，適応的諦観を介した負の 間接効果を示し, 正と負という機能の 2 面性が存在す ることが明らかになった。また，ポジティブな精神的 健康に対しては, 適応的諦観を考慮しない場合, ポジ ティブな精神的健康を高める機能を有していることが 示唆されるが，実際には適応的諦観を完全に媒介する 形で機能していることが明らかになった。これにより, 
ストレスへのモニタリング志向が適応的諦観を媒介し て精神的健康と関連するというモデルにおいて，ス卜 レスへのモニタリング志向は，（a）ポジティブな精神 的健康へ負の直接効果と適応的諦観を介した正の間接 効果を示す，（b）衤ガティブな精神的健康へ正の直接 効果と適応的諦観を介した負の間接効果を示す，とい う本研究の 2 つの仮説はほぼ支持されたものと考えら れる。一部, ストレスへのモニタリング志向とポジティ ブな精神的健康に負の直接効果はみられなかったが, これは従来想定していたストレス，すなわちネガティ ブな精神的健康とポジティブな精神的健康の質的な異 なりが影響している可能性が考えられる。認知行動療 法において，またこれまでの国の取り組みの中でも, ストレスのモニタリングを単に促進すべきものとして 捉える傾向が目立つが，モニタリングの精神的健康に 対するアンビバレントな機能と共に, 媒介変数として の適応的諦観の重要性が示唆される。

諦観についてはこれまで，その非適応的側面につい て強調されることが多かった。もちろん, コーピング においてただ単に諦めることが非適応に繋がる場合が あることは数多く指摘されており, 多くの人が実感す るところであろう。しかし, 本研究は適応的諦観が, ストレスへのモニタリング志向というストレスに対す る認知行動的アプローチの重要概念と密接に関連して おり, 精神的健康に対する機能を考える上で非常に重 要な役割を果たすことを示唆している。そもそも，心 理学の領域におけるレジリエンスとは, ストレスフル な経験や脅威的な状況に置かれているにもかかわら ず, 精神的健康や適応的な行動を維持できる能力や特 性を意味し, 楽観性, 意欲的活動性, 関係志向性の側 面を有する（大森，2014）。そして，ハーディネスが ストレッサーに対する頑健性を意味する一方で，レジ リエンスはストレッサーの影響を受けるが，認知の変 容やコーピング方略により回復する力を意味する（大 森，2014）。適応的諦観はまさに楽観性を取り入れた 諦観的態度であり，レジリエンスの一種として位置づ けることができる。一方，諦観や「諦め」は，日本文 化に特徵的な心のあり方として指摘されており（富樫， 2006), 適応的諦観が社会的な規範意識の強い日本人 に特徴的なレジリエンスである可能性も考えられる。

\section{認知行動療法とセルフモニタリング, 適応的諦観}

本研究で用いた適応的諦観は認知的態度であり, 介 入可能性の高い変数と考えられる。認知療法との関連 でいえば, 自分のネガティブな反応に気づいた時に, どうそれを柔軟に捉えられるかが大事であり，適応的 諦観はまさにそういった認知的態度の1つとして位置 づけることができるだろう。認知行動療法では近年, 事象そのものではなく, 事象との距離の取り方（杉浦, 2008）に着目した技法が注目を集めており, マインド
フルネスやアクセプタンスとして概念化されている。 これらの概念では, 思考や感情に「価值判断をしない」 ことや「とらわれない」ことが重要視されている (Kabat-Zinn, 1990 春木訳 2007)。これらの概念は本研 究で概念化された適応的諦観に近いと考えられ，アク セプタンスの訳語としてよく用いられる日本語の「受 容」と「諦め」では一見正反対の概念のように見える ものの, それらの概念が重なる部分を描き出している と考えられる。近年日本でもマインドフルネスが注目 され, 研修等も多数行われているが, 欧米で概念化さ れたものであるため直感的に理解しづらいことが課題 の1つとなっている。本研究の結果を踏まえて, 日本 語の「諦める」という言葉を用いながら「価值判断を しない」ことや「とらわれない」ことの重要性を述べ ることも, 理解の上で役立つ可能性がある。

またこれまで，文化差に着目し，日本人に特徵的な 心のあり方を描き出そうとする試みはこれまで多くの 研究者によって行われてきた。高田（2004）はそれら をまとめ, 日本人の自己の構造の特徵として,「外的 客我が強く内的客我を圧倒しがちなこと」，その結果 としての「主我の弱体化・不安定さ」の 2 つを挙げて いる。ストレスへのモニタリングを含む認知行動療法 は西洋の相互独立的自己観（北山，1994）を根底にセ ルフケア，すなわち高田（2004）の言葉を使えば，主 我の強化・安定化を目的とするものである。しかしな がら，日本人のように外的客我が強く内的客我が圧倒 されている場合には，まず外的客我を外的客我と認識 することが難しいと考えられ，西洋的な自己観に基づ いたサポートがむしろその外的客我の強化とそれによ る主我の弱体化・不安定さに繋がる場合も多いと考え られる。本研究でみられたストレスへのモニタリング 志向の精神的健康に対するアンビバレントな機能はこ れを裏づけるものであり，精神的な不調に陥っている 場合には，まず外的客我と内的客我とも見分けのつか ない客我を一度脇において手放すという諦めの作業を 行い, 適応的諦観を育てていくことが必要であると考 えられる。

\section{産業領域でのストレス教育における応用可能性}

平成 26 年 6 月に労働安全衛生法の改正が公布され, 平成 27 年 12 月より, 労働者数が 50 人以上の事業場 では, 労働者に対して医師や保健師等によるストレス チェックを実施することが義務付けられた。そしてス トレスチェックの結果一定の要件に該当する労働者か ら申し出があった場合は，医師による面接を実施する こと, そして必要に応じて就業上の措置を講じること が事業者の義務となっている。このように, 自己のス トレスを把握し, 必要に応じて専門家の支援を受ける など，労働者自身がストレスに適切に対処することが ますます求められる時代となっている。 
そのため, 企業で働く労働者を対象に行われてきた メンタルヘルス教育研修においても, 認知行動療法を 用いたものが増加しており，職業上のストレス軽減の 上で最も効果的であるとされる（Van der Klink, Blonk, Schene, \& van Dijk, 2001)。仕事上のストレスに対処す るための認知行動的アプローチの具体的な内容は，よ り機能的な行動反応を練習することにより, 認知や感 情をより適応的なものに変容させることで，ネガティ ブな思考, 感情および結果としての行動を管理できる ように導く（Richardson \& Rothstein, 2008）というもの である。このような認知行動的アプローチの具体的な 取り組みとしては，ストレッサーへの気づきの援助, そしてストレッサーへのコーピング方略の検討と変容 の2つが有効であると考えられている（田中，2009）。

本研究でみられた媒介効果からは，ストレス教育研 修の形式でメンタルヘルス向上を目指す際に, 単にス トレスへのモニタリングの重要性を強調するだけでな く, 適応的諦観という認知的態度を重視する必要性が 明らかになった。ストレッサーの気づきの援助として は，自己のストレスに対する意識を高め，何が自分に とってストレッサーとなっているのか, 何がストレス 反応なのかを，モニタリングし把握することが不可欠 である。特に，ストレス反応としての身体的疲労の蓄 積や, 落ち込みや焦燥感などの精神的不調は他者から は気づきにくく，本人が自己の状態に気づき，対処す るスキルを身につけることが非常に重要である。しか しながら，モニタリングだけでは不十分であり，適応 的諦観という認知的な要素を踏まえた上でメンタルへ ルス支援を行っていくことが望ましい。また，労働者 自身に上記の知見をわかりやすく伝えることにより， 自分の傾向に自覚的であることでモニタリングの悪影 響を減じることができる可能性がある。

また，この適応的諦観の最終的な尺度項目には，現 在起こっているネガティブな出来事を全てととらえ ず，未来や過去に起こる出来事と比較して位置づける 項目が多く含まれている。これは時間的展望の概念と 関係が深いと考えられる。時間的展望とは「個人の現 在の事態や行動を過去や未来の事象と関係づけたり, 意味づけたりする意識的な働き (白井, 1994)」とされ， 本研究との関連でいえば，現実を現実として受け入れ つつ，それが全てではないととらえることも大事であ ることが示された。この時間的展望を促進する方法に ついては複数開発されており, 将来コラージュ法や展 望地図法などによる介入が試みられている（園田, 2007)。適宜時間的展望を高める方法についても活用 していくことが, 適応的諦観についての理解と対応を 深めることに繋がると考えられる。

\section{限界と展望}

本研究の限界として, 1 回のみの横断調査であるこ
とが挙げられる。そのため, 因果関係についてはあく まで推定にすぎず，縦断調査を用いてょり詳細な検討 を行っていく必要がある。併せて, 本研究の対象者は 20 代一 40 代のフルタイム労働者 600 名という限られ た範囲の人々を対象としている。フルタイム労働者に より強いと考えられる社会的規範意識の検討と併せ て, 今後幅広い年代・就労形態の人々を対象にし, 結 果の一般化可能性について検討を重ねていくことが求 められる。また, 本研究ではストレッサーの強度や種 類について扱ってはいないがそれらの要素によって, 適応的諦観や精神的健康との関連が異なってくる可能 性がある。今後, 今回論じた適応的諦観の認知行動療 法への応用可能性を踏まえつつ，どのようなストレッ サーに対して適応的諦観を用いるのが適切であるかを 吟味する必要がある。また, 本研究ではポジティブメ ンタルヘルスとストレスを用いたが，ストレスへのモ ニタリング志向は心理的介入の基礎的な要素となって おり，より焦点を絞った変数についてもその機能を検 討していくことが期待される。例としては抑うつや不 安, 強迫傾向といった臨床場面でよく用いられる精神 的健康指標が挙げられる。また, 社会的規範意識や諦 観については文化差が存在する可能性も指摘されてお り，異なった文化圈のサンプルではストレスへのモニ タリングや適応的諦観について異なった機能を有する 可能性がある。今後国際比較研究を行い, 各国の文化 やネガティビティへの意識を踏まえながら知見を積み 重ねることが期待される。

\section{引用文献}

浅野 憲一（2010）。わりきり志向尺度の作成抒よび精 神的健康, 反応スタイルとの関係 パーソナリ ティ研究, 18, 105-116.

Carver, C. S., Scheier, M. F., \& Weintraub, J. K. (1989). Assessing coping strategies: A theoretically based approach. Journal of Personality and Social Psychology, $56,267-283$.

Feifel, H., \& Strack, S. (1989). Coping with conflict situations: Middle-aged and elderly men. Psychology and Aging, 4, 26-33.

平野真理 (2010)。レジリエンスの資質的要因・獲得 的要因の分類の試み——次元レジリエンス要因 尺度（BRS）の作成——パーソナリティ研究, 19, 94-106.

星野崇宏・岡田謙介・前田忠彦 (2005)。構造方程 式モデリングにおける適合度指標とモデル改善に ついて一一展望とシミュレーション研究による新 たな知見——行動計量学, 32, 209-235.

今津芳恵 - 村上 正人 - 小林恵 - 松野俊夫 - 椎原康史 石原慶子…临玉昌久 (2006)。Public Health Research Foundation ストレスチェックリスト・ ショートフォームの作成一信頼性・妥当性の検 討——身医学, 46, 301-308. 
Kabat-Zinn, J. (1990). Full catastrophe living. New York: Delacorte Press.

（カバットジン, J. 春木 豊（訳）（2007）. マイン ドフルネスストレス低減法 北大路書房)

神村栄一 ・海老原由香 - 佐藤健二 ・ 戸ヶ崎泰子 - 坂 野 雄二 (1995). 対処方略の三次元モデルの検討 と新しい尺度（TAC-24）の作成 筑波大学教育 相談研究, 33, 41-47.

加藤 正明 $(2000)$. 労働省平成 11 年度「作業関連疾 患の予防に関する研究」労働の場におけるストレ ス及びその健康影響に関する研究報告書, 117164.

北山忍 (1994). 文化的自己感と心理的プロセス 社 会心理学研究, 10, 153-167.

清川雪彦・山根弘子 (2004). 日本人の労働観一一意 識調査にみるその変遷— 大原社会問題研究所 杂隹誌, 542, 14-33.

厚生労働省 (2000). 事業場における労働者の心の健康 づくりのための指針 Retrieved from http://www2. mhlw.go.jp/kisya/kijun/20000809_02_k/20000809_02_ k_shishin.html (2016 年 12 月 26 日)

厚生労働省 (2006). 労働者の心の健康の保持増進の ための指針 Retrieved from https:/www.jaish.gr.jp/ anzen/hor/hombun/hor1-20/hor1-20-10-1-0.htm (2016 年 12 月 28 日)

小杉 正太郎 - 田中 健吾 - 大塚 泰正 - 種市 康太郎 - 高 田未里・河西真知子…米原奈緒 (2004). 職場 ストレススケール改訂版作成の試み（I）—ス トレッサー尺度・ストレス反応尺度・コーピング 尺度の改訂—産業ストレス研究, 11, 175185.

熊野 宏昭 (2012)。新世代の認知行動療法 日本評論 社

宗像 恒次 (1996)。最新行動科学から見た健康と病気 メヂカルフレンド社

日本マインドフルネス学会 (2017). 設立趣旨 Retrieved from http://mindfulness.jp.net/concept.html (2017 年 3 月 15 日)

大森 美香 (2014). ストレスと性格 下山晴彦 (編) 心理学辞典 (pp. 340-341) 誠信書房

Richardson, K. M., \& Rothstein, H. R. (2008). Effects of Occupational Stress Management Intervention Programs: A meta-analysis. Journal of Occupational Health Psychology, 13, 69-93.

嶋大樹 - 柳原 茉美佳 · 川井 智理 · 熊野宏昭 (2013). 日本語版 Acceptance and Action Questionnaire-II 7 項目版の検討 日本心理学会第 77 回大会発表論 文集，271.

島 悟 (2006). 労働者の心の健康の保持増進のための 指針 産業精神保健, 14, 172-175.

島津 明人 (2013). 科学的根拠に基づいた職場のメン タルヘルスの第一次予防のガイドライン——職場 のメンタルヘルスのためのセルフケア教育のガイ ドライン——産業ストレス研究, 20, 127-133.

清水 裕士 (2016)。フリーの統計分析ソフト HAD 一機能の紹介と統計学習・教育, 研究実践にお ける利用方法の提案——メディア・情報・コミュ ニケーション研究, 1,59-73.
新村 出（編）（1998）。広辞苑第五版 普通版 岩波書 店

白井 利明 (1994)。時間的展望体験尺度の作成に関す 万研究 心理学研究, 65, 54-60.

園田直子（2007）。自分を知り，生きがいをつくる 都筑学・白井利明(編) 時間的展望研究ガイドブッ ク（pp.140-150） ナカニシヤ出版

菅沼 慎一郎 (2013). 青年期における「諦める」こと の定義と構造に関する研究 教育心理学研究, 61 , $265-276$.

菅沼 慎一郎 (2014)。諦めることに対する認知尺度の 作成と検討 臨床心理学, 14,81-89.

菅沼 慎一郎 (2015). 青年期において諦めることはど のように体験されるか一プロセスに着目して ——発達心理学研究, 26, 23-34.

菅沼慎一郎・平野真理 - 中野美奈・下山晴彦 (2016). 日本語版 Warwick-Edinburgh Mental Well-being Scale （WEMWBS）の作成と信頼性・妥当性の検討— hedonic/eudaimonic を包括した状態指標——臨 床心理学, 16, 471-475.

杉浦 義典 (2008)。 マインドフルネスにみる情動制御 と心理的治療の研究の新しい方向性 感情心理学 研究, 16, 167-177.

鈴木 伸一 (2004). 3 次元（接近-回避, 問題-情動, 行動-認知）モデルによるコーピング分類の妥当 性の検討 心理学研究, 74, 504-511.

鈴木 伸一・嶋田 洋徳 · 三浦 正江 ·片柳 弘司 - 右馬埜 力也・坂野雄二 (1997). 新しい心理的ストレス 反応尺度 (SRS-18) の開発と信頼性・妥当性の 検討 行動医学研究, 4, 22-29.

高橋 美保 (2005).「働くこと」の意識についての研 究の流れと今後の展望 東京大学大学院教育学研 究科紀要, $45,149-157$.

高田 利武（1999）。 日本文化における相互独立性・相 互協調性の発達過程一比較文化的 - 横断的資料 による実証的検討——教育心理学研究, 47, 480-489.

高田 利武 (2004).「日本人らしさ」の発達社会心理 学一自己・社会的比較・文化—— ナカニシヤ 出版

田中 健吾 (2009). 職業ストレスとカウンセリング 白樫 三四郎 (編) 産業・組織心理学への招待 (pp. 117-135）有斐閣

田中 道弘 (2008). 自尊感情における社会性, 自尊感 情形成に関しての基準—自己肯定感尺度の新た な可能性——斗米 淳 (編) 社会心理学への アプローチ (pp. 27-45) 榎本 博明・岡田努・下 斗米 淳 (監) 自己心理学 6 金子書房

Tennant, R., Hiller, L., Fishwick, R., Platt, S., Joseph, S., Weich, S., ... Stewart-Brown, S. (2007). The WarwickEdinburgh Mental Well-being Scale (WEMWBS): Development and UK validation. Health and Quality of Life Outcomes, 5, 63.

富樫 公一 (2006). 「意地」自己心理学的考察——蒼古 的自己愛空想への執着と諦め—— 精神分析研 究, 50, 365-374.

上田 㻟哉（1996）。自己受容概念の再検討一一自己評 価の低い人の「上手なあきらめ」として—— 心 
理学研究, 67, 327-332.

Van der Klink, J. J., Blonk, R. W., Schene, A. H., \& van Dijk, F. J. (2001). The benefits of interventions for work-related stress. American Journal of Public Health, 91, 270-276.

Westbrook, D., Kennerley, H., \& Kirk, J. (2011). An introduction to cognitive behavioural therapy: Skills and applications (2nd ed.). London: Sage Publications.

(ウエストブルック , D.・ケナリー, H.・カーク , J .
下山晴彦（監訳）（2012）。認知行動療法臨床ガ イド 金剛出版)

山本 美奈子 ·宗像 恒次 (2012). 労働者のメンタルヘ ルスと行動特性の影響——共分散構造分析による 因果モデルの検証——産業衛生学雑誌, 54, 1021.

- 2017.3. 24 受稿, 2018.3.18 受理 